\title{
A Comparative Analysis of the Productivity of Islamic and Conventional Mutual Funds in Indonesia: Data Envelopment Analysis (DEA) and General Least Square (GLS) Approaches
}

\author{
M. Shabri Abd. Majid \\ Syiah Kuala University, Banda Aceh, Indonesia \\ HartomiMaulana \\ Islamic Economic Forum for Indonesian Development (ISEFID), Malaysia
}

\begin{abstract}
This paper is an extended version of our earlier study (Abd. Majid and Maulana 2010) to further re-examine the relative efficiencies of selected Islamic and conventional mutual funds companies in Indonesia during the period 2004 to 2007 and their determinants. To measure their efficiencies, the output-input data consisting of a panel of conventional and Islamic mutual funds companies are empirically examined based on the most commonly used non-parametric approach, namely, Data Envelopment Analysis (DEA). It also attempts to investigate the influence of the mutual funds companies' characteristics on efficiency measures using the Generalized Least Square (GLS) estimation.

The study finds that, on average, the Indonesian mutual funds companies experienced a decrease in Total Factor Productivity (TFP) growth. It is mainly caused by a decline in both efficiency and technical efficiencies, where the efficiency change is largely contributed by the changes in pure efficiency rather than scale efficiency. Additionally, the study also documents that the funds size negatively affects efficiency. This indicates that due to its diseconomies of scale, a larger mutual funds company is less efficient than a smaller funds company. Finally, in comparing the efficiency of the mutual funds companies, the study finds that, on average, the Islamic unit trust companies perform more poorly than their conventional counterparts.
\end{abstract}

Abstrak: Tulisan ini adalah versi ringkas dari penelitian kami sebelumnya (Abd. Majid dan Maulana 2010) untuk lebih meneliti kembali efisiensi relatif yang dipilih perusahaan Islam dan konvensional reksadana di Indonesia (2004-2007) dan penentunya. Untuk mengukur efisiensinya, output-input data yang terdiri dari sebuah panel konvensional maupun syariah perusahaan reksadana secara empiris diteliti berdasarkan pada pendekatan non-parametrik yang paling umum digunakan, yaitu, Data Envelopment Analysis (DEA). Hal ini juga mencoba untuk meneliti pengaruh karakteristik reksa dana perusahaan pada efisiensi langkah-langkah dengan menggunakan estimasi Generalized Least Square (GLS).

Studi ini menemukan bahwa, rata-rata, perusahaan reksadana di Indonesia mengalami penurunan total faktor pertumbuhan produktivitas. Hal ini terutama disebabkan oleh penurunan efisiensi dan efisiensi 
teknis, di mana perubahan efisiensi sebagian besar disumbang oleh perubahan dalam efisiensi murni daripada efisiensi skala. Selain itu, studi ini juga mendokumentasikan bahwa ukuran dana negatif mempengaruhi efisiensi. Hal ini menunjukkan bahwa karena dis-ekonomi atas skala, reksa dana perusahaan besar kurang efisien daripada perusahaan dana yang lebih kecil. Akhirnya, dalam membandingkan efisiensi dari perusahaan reksa dana, studi ini menemukan bahwa, rata-rata performa kepercayaan perusahaan unit syariah lebih buruk daripada rekan-rekan konvensional mereka.

Keywords: Data Envelopment Analysis (DEA); efficiency; Generalized Least Square (GLS); Indonesia; Islamic capital market; Mutual funds 


\section{Introduction}

Measuring and comparing the performances of mutual funds' companies have become a main concern for investors and managers in the finance industry. ${ }^{1}$ Information about the performances of mutual funds is one of the major considerations taken into account by investors in the fund-selection decision. Meanwhile, by referring to mutual funds' performances, it enables fund managers to move towards better pricing, attracting greater inflow of funds and improving their profitability. Thus, knowing their performances, fund managers can design a proper strategy and policy to improve their competitive ability against their competitors.

Unlike many empirical studies that have been conducted to investigate the performances of conventional mutual funds, studies on the performance of Islamic mutual funds have been meagre. Among them are those that were conducted by Annuar et al. (1997); Hayat (2006); Md. Taib and Isa (2007); Abdullah et al. (2007); and Ferdian and Dewi (2007). By using the model developed by Treynor and Mazuy (1966), Annuar et al. (1997) examined the performances of 31 conventional and Islamic mutual funds in Malaysia for the period 19901995. They found evidence that these Malaysian funds outperformed their benchmark but were poor at timing the market. Furthermore, they also found a positive correlation between the market timing ability and security selection ability. Meanwhile, Hayat (2006) utilized the Sharpe Ratio (SR), the Treynor Ratio (TR), the Information Ratio (IR), the Modigliani and Modigliani measure (MM), and the TT measure (TT) to empirically assess the performances of 44 Islamic equity fund returns in Malaysia during the period from $17^{\text {th }}$ August 2001 to $25^{\text {th }}$ August $2006 . \mathrm{He}$ found that the Islamic equity funds were relatively safe investment vehicles. During the normal market condition, there were no significant differences between the performances of Islamic and conventional funds. During the bear market of 2002, the Islamic equity funds however significantly outperformed the conventional markets. Furthermore, Islamic equity funds seemed to be most attractive as part of a larger fully diversified portfolio as they have good systematic riskto-return ratios.

Unlike the above studies that only investigated the performances of mutual funds in Malaysia, Ferdian and Dewi (2007) employed the Sharpe, Treynor and Jensen Indexes to comparatively explore the performances of 5 Islamic funds in Indonesia with 20 Islamic funds in Malaysia over the period October 1, 2005 to April 30, 2007. They found that the Malaysian Islamic funds seem to outperform the Indonesian Islamic mutual funds. This could be partly due to the fact that the Malaysian mutual funds have been relatively more established as compared to the mutual funds in Indonesia. All the above reviewed studies have used traditional methods to investigate the performances of the Islamic mutual funds both in Indonesia and Malaysia.

One recent approach to the evaluation of mutual funds performance is by measuring its efficiency. Two approaches have been used to measure efficiency, namely parametric and nonparametric. The Stochastic Frontier Approach (SFA) -parametric and Data Envelopment Analysis (DEA)- non-para-

${ }^{1}$ Mutual Funds are also generally called 'Reksadana' in the Indonesian acronym. As the term mutual funds are commonly used in Indonesia rather than the term unit trusts, thus this study adopts this terminology. 
metric, have been widely used in the literature to measure the efficiency of mutual funds. The SFA is an econometric frontier approach which specifies a functional form for the cost, profit, or production relationship among inputs, outputs, and environmental factors, and allows for random error. However, SFA suffers from strong assumptions, particularly when econometrics has to deal with the hypothesis required on the distribution of the inefficiency component and its independence from other factors determining producer behavior.

Meanwhile, the DEA is a non-parametric method that has been widely employed in operations research to compute relative measures of efficiency of mutual fund companies due to its advantages. DEA takes into account many factors that are associated with the funds' performance and considers mutual funds' performance indexes with different risk measures and investment costs. In addition, the DEA enables the identification of the relative importance among the inputs (transaction costs); for example, we can observe the marginal contribution of each input in affecting returns (Jemric and Vujcic 2002). Since the DEA does not take into account random errors, we can assume that the error term is normally distributed (Pallegrina 2005). Therefore, the mathematical programming procedures used by the DEA for efficient frontier estimation is comparatively robust (Seiford and Thrall 1990). Finally, the DEA also provides robust findings when the sample size of a firm is small (Maghyereh 2004; and Neal 2004).

In measuring performances of mutual funds, both in the developed and emerging economies, the DEA have been adopted by few studies. Murthi et al. (1997) and Choi and Murthi (2001) measured performances of mutual funds in the US, while Basso and
Funari (2001) and Galagedera and Silvapulle (2002) investigated performances of mutual funds in Italy and Australia, respectively. On the other hand, Chen and Lin (2006) assessed the performance of mutual funds in the emerging economy of China.

Abd. Majid and Maulana (2010) have assessed the performances of the conventional mutual funds in Indonesia, but no further empirical investigation was made to explore the likely factor affecting their performances. As an extended version of our earlier study (Abd. Majid and Maulana 2010), this study does not only measure the performance of the conventional mutual funds, but it also explores the performance of the Islamic mutual funds in Indonesia. In addition, this study also attempts to determine the factors affecting the performances of both conventional and Islamic mutual funds.

In view of the above research scenario, thus this present study intends to fill the gap by applying the DEA and GLS to investigate the determinants of productivity of selected conventional and Islamic mutual fund companies in Indonesia. Apart from using the DEA and GLS, another innovative aspect of this study is that it compares the efficiency of the conventional mutual fund companies with that of the Islamic counterparts. The performance of the conventional and Islamic mutual funds are expected to be different, since the former are subject to the capital market rules, while the Islamic unit trusts are subject to both the capital market rules and shari'ab principles. Despite the fact that more than 90 percent of the shares listed are shariah-compliant, the remaining 10 percent of the shares listed may comprise highly profitable non-shari'ah-compliant activities. According to Ghoul et al. (2007), companies which are not acceptable based on Islamic principles include the majority of financial 
institutions involved in money lending and the charging of interest, such as banks and insurance companies. Other screening criteria prohibit investments involving the production, distribution and/or earning profits from alcohol, pornography, tobacco, gambling, weapons, music, entertainment, processing pork meat or non-halal meat, hotels and airlines which serve alcohol.

Comparing and contrasting the productivity of the two types of mutual funds industry is important and relevant for Indonesia, because of its dual financial system, in which Islamic mutual funds companies operate parallel with their conventional counterparts. The comparison thus sheds light on the performance of the Islamic mutual funds companies, whose operations are limited to selected shariah-compliant companies, as opposed to the conventional mutual funds companies which can invest in any suitable companies that can potentially give the highest return. Ultimately, the findings of the study are expected to contribute towards improving the productivity of the mutual fund industry in Indonesia as a whole.

While the study of mutual funds' performance is gaining attention in the developed countries and some other emerging economies, research on an open-big developing country of Indonesia has been in existence. Despite the mutual funds' industry (both conventional and Islamic funds) having experienced phenomenal growth in Indonesia, the study on performance and efficiency of the Indonesian mutual funds is highly important and timely. Thus, this study attempts to re-examine the productivity of selected conventional and Islamic mutual fund companies in Indonesia using the DEA and GLS for the period of 2004 -2007 with the following specific objectives:

(i) To empirically re-examine the relative efficiency of the mutual funds companies in Indonesia;

(ii) To compare the productivity of conventional and Islamic mutual funds in Indonesia; and

(iii) To empirically explore the effect of funds characteristics such as fund's size and profitability on the efficiency of the mutual funds companies in Indonesia.

The rest of this study is structured as follows. Section 2 provides a brief overview of the Indonesian mutual funds industry including Islamic mutual funds. Section 3 describes the data and discusses the methodology of the DEA. Section 4 presents the results and analysis, and Section 5 concludes.

\section{An Overview of Mutual Funds' Industry in Indonesia}

According to the Capital Market Act No. 8 (1995), mutual fund refers to when an investment company, that has been approved by the Supervisory Capital Market of Indonesian Agency (BAPEPAM), ${ }^{2}$ pools money from shareholders and invests in a diversified portfolio of securities. ${ }^{3}$ Mutual fund investment is simple, accessible, and affordable. There are many advantages of investing through mutual funds such as professional

${ }^{2}$ BAPEPAM (Badan Pengawas Pasar Modal) is a capital market supervisory agency which reports and is responsible to the Minister of Finance. BAPEPAM shall provide guidance, regulation, and day to day supervision of the capital market.

${ }^{3}$ UU Pasar Modal RI, No.8 (1995), Bab IV [Capital Market Law Republic of Indonesia No.8 (1995) Chapter IV]. See http://www.BAPEPAM.go.id/pasar_modal/regulasi_pm/uu_pm/index.htm. 
management, diversification, variety, liquidity, affordability, convenience, and ease of record keeping as well as strict government regulations and full disclosure (Investment Company Institute 2004). Mutual funds were first introduced in Indonesia within the framework of the Capital Market Act No. 8 (1995).

After the first mutual fund, BDNI Reksadana, was instituted in 1996, in the same year there were 25 mutual funds were established with the total amount of funds managed of Rp2.78 trillion (see Table 1). In 1997, the number of mutual funds has significantly increased to 77 (208 percent) from 1996 with the total funds managed of Rp4.91 trillion.

The development of the mutual funds' industry in Indonesia has been very much influenced by macroeconomic conditions. When the 1997 financial turmoil hit the country, the growth of mutual funds slowed down. In 1998, the number of issuers only grew by 5.19 percent and the value of issuers decreased dramatically by 39.22 percent from the year 1997. A worse condition occurred in the bond market where there was virtually no new issues during this period (BAPEPAM Master Plan 2005-2009).

However, the industry grew more rapidly after 2002, due to the dramatic increase in fixed-income funds, which were invested mainly in the Rupiah-denominated government securities. Declining interest rates (and rising bond prices) provided a favourable environment for launching recap bond funds. At the end of 2004, mutual funds were amounting to Rp104 trillion or US\$10.4 billion (see Table 1). In 2005, BAPEPAM reported that the number of managed funds dramatically fell by 72 percent from Rp104.04 trillion in 2004.
Moreover, when the world fuel price increased, which lead to cost-push inflation, the interest rate which called the Central Bank Certificate Rate (SBI - Sertifikat Bank Indonesia) rose to 12.75 percent. As a result, the banking industry has to increase its deposit interest in order to attract more customers. This condition might cause the investors to withdraw their funds from the mutual funds to the bank depository. Finally, in line with the Indonesian economic recovery agenda to lower interest rates, inflation, and to increase the stock market composite index, the mutual funds become again more attractive for investors. The number of managed funds has significantly increased from Rp29.40 trillion in 2005 to Rp51.62 trillion at the end of 2006.

In terms of their types, mutual funds in Indonesia is generally divided into five types, namely equity, fixed-income, money market, balanced-mixed and protected funds. As of 2005, fixed income holds the largest portion which reached 47.3 percent of total net asset value, followed by balance fund is 18.5 percent, while money market fund recorded the lowest which only 0.7 percent. The biggest portion of fixed income was mainly invested on debt/securities issued by government (2.4 percent of total) and corporate (45.1 percent of total). Since interest rate set by Bank of Indonesia increased to around 12 percent as to maintain currency and inflation rate was badly affected the bond price. High interest rates made the investment in bonds less attractive, and it drove the investor to redeem their investment in fixed income fund. This situation made a decrease significantly in Net Asset Value of funds as fixed income holds the biggest portion of the portfolio at the end of 2005. 


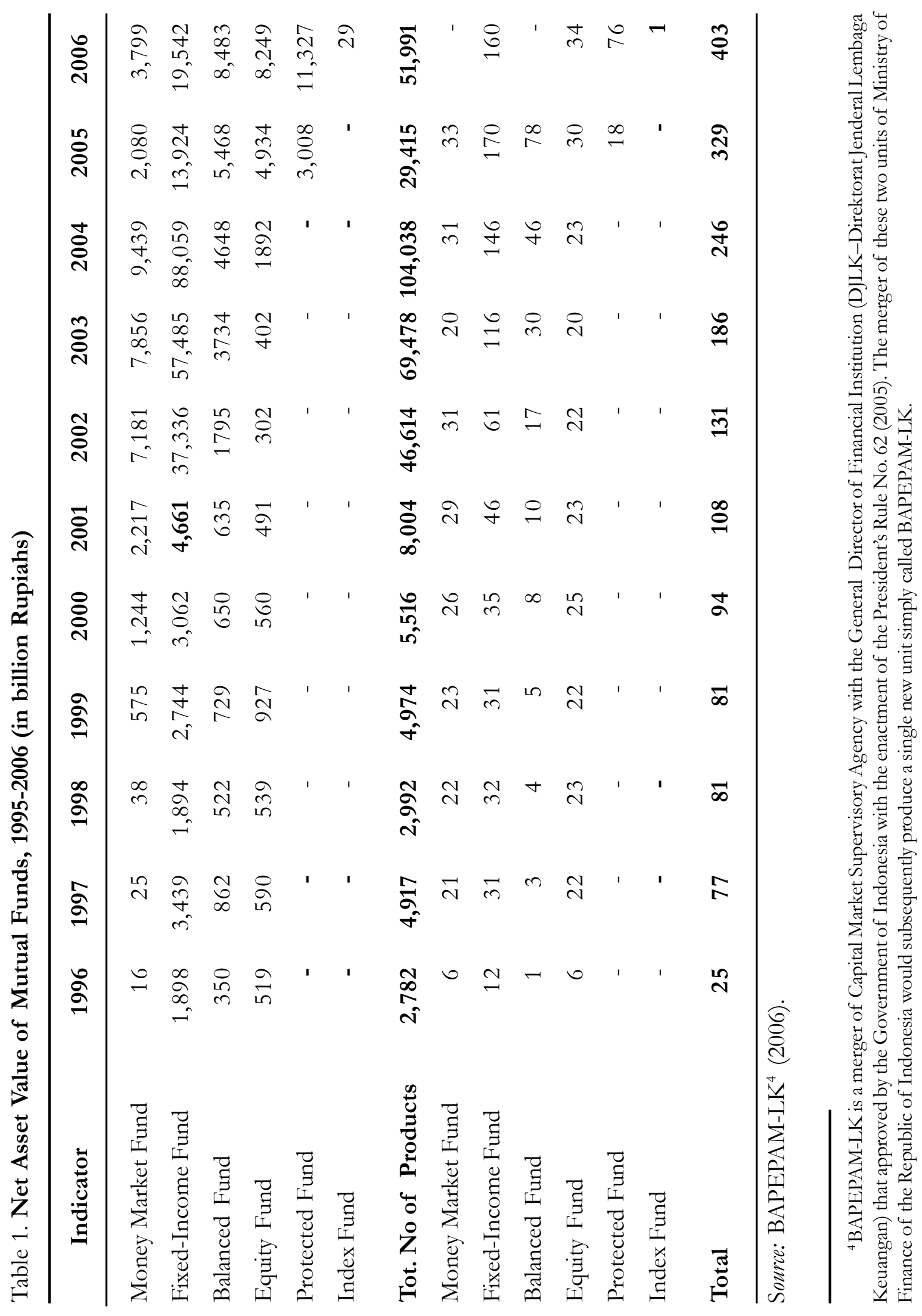


Hitherto, the mutual funds industry in Indonesia has been playing an important role in promoting economic growth of the country. As reported by BAPEPAM, in 2006, the mutual fund industry experienced a positive increase after suffered a massive redemption in 2005. It can be seen from the increasing of the Net Asset Value from Rp29.40 Trillion in 2005 to Rp51.43 Trillion in 2006 which contributed 2.4 percent of total financial assets and 1.5 percent of GDP or increased 0.4 percent of GDP from 2005 (see Table 2).

In Indonesia, the Islamic funds appear in almost all Unit Trust Management Companies (UTMCs). These funds are invested in Shariah-compliant financial assets such as
Shariah-approved stocks, Islamic bonds (Sukuks), Islamic deposits and money market instruments. An Islamic UTMC is one that offers only Shariah-approved funds. These can be equity, bond, or balance funds. Like conventional mutual funds, Islamic funds also impose the charge fees to investors. Basically, there are three types of fees, namely entry load (front load), redemption fees and management expense ratio. Since the investors pay the management company fees and commission, the contract cannot resemble equity such as mudharabah and musharakah. It looks like the UTMC is appointed by investors as an agent (wakil) to manage the funds. Thus, the contract of agency (wakalah) seems to be more accurate. However, a UTMC does not

Table 2. Structure of Financial Sector

\begin{tabular}{lrrrrrr}
\hline Type of Institution & Assets (Rptrillion) & Asset (\%) & \multicolumn{2}{c}{ GDP *(\%) } \\
\cline { 2 - 7 } & $\mathbf{2 0 0 5}$ & $\mathbf{2 0 0 6}$ & $\mathbf{2 0 0 5}$ & $\mathbf{2 0 0 6}$ & $\mathbf{2 0 0 5}$ & $\mathbf{2 0 0 6}$ \\
\hline Banks & 1,470 & $1,693.5$ & 78.8 & 80 & 52.7 & 51.3 \\
Non-bank financial institutions & 393.9 & 425.4 & 21.1 & 20 & 14.1 & 13.4 \\
Finance Companies & 67.7 & 108.9 & 3.6 & 5.1 & 2.4 & 3.2 \\
Insurance Companies & 75.1 & 94.7 & 4.0 & 4.4 & 2.6 & 2.8 \\
Pension funds & 63.4 & 77.4 & 3.4 & 3.7 & 2.2 & 2.3 \\
Pawnshops (Pegadaian) & 4.8 & 6.0 & 0.2 & 0.3 & 0.1 & 0.1 \\
Rural institutions & 20.3 & 23.0 & 1.0 & 1.0 & 0.7 & 0.6 \\
Mutual funds & 29.4 & 51.6 & 1.5 & 2.4 & 1.1 & 1.5 \\
Venture capital companies & 2.7 & 2.3 & 0.1 & 0.1 & 0.1 & 0.1 \\
Outstanding corporate bonds & 62.8 & 61.5 & 3.3 & 3.0 & 2.2 & 1.8 \\
Total & 1863.9 & 2118.9 & 100 & 100.0 & 66.9 & 63.4 \\
Equity market capitalization & 801 & 1,249 & n.a & n.a & 28.7 & 37.4 \\
\hline
\end{tabular}

Source: Bapepam-LK, Bank Indonesia, Indonesia Stock Exchanges (IDX), 2006.

Note: *GDP 2005:2,785.0 trillion and GDP 2006: 3,338.2 trillion 
serve as an agent (wakil) who is allowed to manage the funds without control and supervision. To prevent moral hazards, a trustee is appointed to safeguard the interest of investors. The trustee will act as a custodian to the funds and will ensure that investments are properly run according to the true label. Thus, it is correct to say that the trustee business runs on the contract of wadiah amanah.
The first Islamic mutual funds (or Reksadana Syariah in Indonesian acronym) introduced in Indonesia was Reksadana PNM (Permodalan Nasional Madani) Syariah on 15 May, 2000 by PT. PNM Investment Management after the formation of the legal framework for Islamic mutual funds. During that year, Danareksa Syariah Berimbang was also established on 12 Nov, 2000 with the net as-

Table 3. The Indonesian Islamic Mutual Funds in 2006 (in Million Rupiahs)

\begin{tabular}{|c|c|c|c|c|}
\hline No & Funds Name & Type & Effective Date & NAV \\
\hline 1. & PNM Syariah & Balanced & 15 May 2000 & $44,144.12$ \\
\hline 2. & Danareksa Syariah Berimbang & Balanced & 12 Nov 2000 & $11,665.14$ \\
\hline 3. & Batasa Syariah & Balanced & $21 \mathrm{Jul} 2003$ & $99,992.48$ \\
\hline 4. & BNI Dana Plus Syariah & Balanced & 21 Apr 2004 & $103,495.71$ \\
\hline 5. & BNI Dana Syariah & Fixed Income & 21 Apr 2004 & $4,682.57$ \\
\hline 6 & Dompet Duafa Batasa Syariah & Fixed Income & $20 \mathrm{Jul} 2004$ & $20,331.23$ \\
\hline 7. & AAA Syariah Fund & Balanced & 14 Aug 2004 & $10,795.88$ \\
\hline 8. & PNM Amanah Syariah & Fixed Income & 26 Aug 2004 & $33,820.90$ \\
\hline 9. & BSM Investa Berimbang & Balanced & 14 Oct 2004 & $12,208.21$ \\
\hline 10. & Big Dana Syariah & Fixed Income & 29 Oct 2004 & 0 \\
\hline 11. & i-Hajj Syariah Fund (RD Haji Syariah & Fixed Income & 13 Jan 2005 & $18,715.90$ \\
\hline 12. & AAA Amanah Syariah Fund & Balanced & 17 Jun 2005 & $22,141.16$ \\
\hline 13 & Capital Syariah Fleksi & Balanced & 4 Aug 2005 & $48,935.12$ \\
\hline 14 & Lautandhana Syariah & Fixed Income & 6 Sep 2005 & $14,671.40$ \\
\hline 15 & Big Dana Syariah Terproteksi & Protected & 5 Oct 2005 & $77,980.56$ \\
\hline 16 & PNM Amanah Syariah Terproteksi & Protected & 5 Oct 2005 & $26,396.64$ \\
\hline 17 & IPB Syariah & Fixed Income & 14 Dec 2005 & $9,117.96$ \\
\hline 18 & Danareksa Indeks Syariah & Equity & 17 Mar 2006 & $29,637.10$ \\
\hline 19 & Kautsar Balanced Growth Syariah & Balanced & 8 Aug 2006 & $41,251.90$ \\
\hline 20 & Euro Peregrine Syariah Balanced Plus & Balanced & 6 Dec 2006 & $33,715.94$ \\
\hline \multicolumn{4}{|c|}{ Total NAV } & 663,700 \\
\hline
\end{tabular}

Source: See www.bapepam.go.id, 2007. 
set value (NAV) amounting to Rp11.66 billion. Generally, the growth of Islamic mutual funds in the country has been very promising.

Three years later in 2003, there were three Islamic funds established with the total NAV at Rp155.8 billion. Seven Islamic funds were declared effective in 2004 with the NAV amounting to Rp185.33 billion. Thus, at the end of year 2004 there was a total of ten Islamic funds that were on offer to the public with the total NAV at Rp341.13 billion. In 2005, the Islamic mutual funds still grew with the issuance of 7 new Islamic mutual funds, which included two protected funds (see Table 3). It means that in total, there were 17 Islamic Mutual funds $(5.2 \%$ from the total number of mutual funds). However, the NAV posted a decrease as a consequence of the declining trend of the bonds market during 2005. The NAV of Islamic mutual funds reached its peak at 1.19 trillion in August before it declined to Rp559.01 billion at the end of the year in 2005 (Bapepam Annual Report 2005).

During 2006, three new Islamic mutual funds were licensed. This means that in terms of the total number of funds, there was a 17.6 percent annual growth. In terms of total NAV there was an annual growth of 18.7 percent. Thus, there was a total of 20 Islamic mutual funds (or $5 \%$ of total mutual funds combined) with total NAV as of 22 December 2006 of Rp663.7 billion (or 1.3\% of total NAV of all mutual funds).

\section{Methodology and Data}

The methodology used in the study is divided into two stages. In the first stage, the efficiency measures are examined by apply- ing the Data Envelopment Analysis (DEA) approach and in the second stage, the efficiency measures are regressed against the mutual funds' specific characteristics based on Generalized Least Square (GLS) estimation.

\section{Data Envelopment Analysis (DEA)}

The methodology used the Data Envelopment Analysis (DEA) approach to measure the relative performance of selected mutual funds in Indonesia. It is a suitable method to be used in this study as our sample size is small (Maghyereh 2004; and Neal 2004). Additionally, DEA is not vulnerable to the disproportion of small sample error as in the econometric model (Dogan and Fausten 2003). We specifically uses the generalized output-oriented Malmquist index, developed by Fare et al. (1989) to measure the contribution from the progress in technology (technical change) and improvement in efficiency (efficiency change) to growth of productivity of the Indonesian mutual funds' industries. The Malmquist indexes are constructed using the DEA and estimated using a program developed by Coelli (1996).

Following Fare et al. (1989), the Malmquist productivity index is written as Equation 1.

$$
\begin{aligned}
M_{0}= & \left(x^{t}, y^{t}, x^{t+1}, y^{t+1}\right)= \\
& \frac{D_{0}^{t+1}\left(x^{t+1}, y^{t+1}\right)}{D_{0}^{t+1}\left(x^{t+1}, y^{t+1}\right)} \times\left[\left(\frac{D_{0}^{t}\left(x^{t+1}, y^{t+1}\right)}{D_{0}{ }^{t+1}\left(x^{t+1}, y^{t+1}\right)}\right)\right. \\
& \left.\left(\frac{D_{0}^{t}\left(x^{t}, y\right)}{D_{0}^{t+1}\left(x^{t}, y^{t}\right)}\right)\right]^{1 / 2}
\end{aligned}
$$


where the notations $D_{0}\left(x^{t+1}, y^{t+1}\right)$, represents the distance from the period $t+1$ observation to the period $t$ technology. The first ratio on the right hand side of the Equation 1 measures the change in relative efficiency (i.e., the change in how far observed production is from the maximum potential production) between year $t$ and $t+1$. The second term inside the brackets (geometric mean of the two ratios) captures the shift in technology (i.e., movements of the frontier function itself) between the two periods evaluated at $x^{t}$ and $x^{t+1}$. That is,

$$
\begin{gathered}
\text { Efficiency Change }= \\
\frac{\mathrm{D}_{0}{ }^{\mathrm{t}+1}\left(\mathrm{x}^{\mathrm{t}+1}, \mathrm{y}^{\mathrm{t}+1}\right)}{\mathrm{D}_{0}^{\mathrm{t}}\left(\mathrm{x}^{\mathrm{t}}, \mathrm{y}^{\mathrm{t}}\right)}
\end{gathered}
$$

Technical Change $=$

$$
\left[\left(\frac{D_{0}^{t}\left(x^{t+1}, y^{t+1}\right)}{D_{0}^{t+1}\left(x^{t+1}, y^{t+1}\right)}\right)\left(\frac{D_{0}^{t}\left(x^{t}, y\right)}{D_{0}^{t+1}\left(x^{t}, y^{t}\right)}\right)\right]^{1 / 2}
$$

Essentially, the former investigates how well the production process converts inputs into outputs (catching up to the frontier) and the later reflects the improvement in technology. According to Fare et al. (1994), improvements in productivity yield Malmquist index values greater than unity. Deterioration in performance over time is associated with a Malmquist index less than unity. The same interpretation applies to the values taken by the components of the overall Total Factor Production Index (TFPI). An improvement in the efficiency component yield index values greater than one and is considered to be evidence of catching up (to the frontier). Values of the technical change component greater than one are considered to be evidence of technological progress.

In empirical applications, the distance measures that appear in Equation 1 are calculated for each operator in each pair of adjacent time periods using the mathematical programming technique. We assume that there are $k=1, \ldots, K$ firms that produce $m=$ $1, \ldots, M$ outputs $y_{k, m}^{t}$ using $n=1, \ldots, N$ inputs $x_{k, n}^{t}$ at each time period $t=1, \ldots, T$. Under DEA, the reference technology with constant returns to scale (CRS) at each time period $t$ from the data can be defined as

$$
\begin{array}{ll}
\mathrm{G}^{\mathrm{t}}=\left[\left(\mathrm{x}^{\mathrm{t}}, \mathrm{y}^{\mathrm{t}}\right): \mathrm{y}_{\mathrm{m}}^{\mathrm{t}} \leq \sum_{\mathrm{k}=1}^{\mathrm{k}} \mathrm{z}_{\mathrm{k}}^{\mathrm{t}} \mathrm{y}_{\mathrm{k}, \mathrm{m}}^{\mathrm{t}}\right] & \mathrm{m}=1, \ldots \mathrm{M}, \\
\sum_{\mathrm{k}=1}^{\mathrm{k}} \mathrm{z}_{\mathrm{k}}^{\mathrm{t}} \mathrm{x}_{\mathrm{k}, \mathrm{n}}^{\mathrm{t}} \leq \mathrm{x}_{\mathrm{n}}^{\mathrm{t}} & \mathrm{n}=1, \ldots \mathrm{N} \\
\mathrm{Z}_{\mathrm{k}}^{\mathrm{t}} \geq 0 & \mathrm{k}=1, \ldots \mathrm{K}
\end{array}
$$

where $z_{k}$ refers to the weight on each specific cross-sectional observation. Following Afriat (1972), the assumption of constant returns to scale may be relaxed to allow variable returns to scales by adding the following restriction:

$$
\sum_{k=1}^{k} z_{k}^{t}=1
$$

Following Fare et al. (1994), this study used an enhanced decomposition of the Malmquist index by decomposing the efficiency change component calculated relative to the constant returns to scale technology into a pure efficiency component (calculated relative to the VRS technology) and a scale efficiency change component which captures changes in the deviation between the VRS 
and CRS technology. The subset of pure efficiency change measures the relative ability of operators to convert inputs into outputs while scale efficiency measures to what extent the operators can take advantage of returns to scale by altering its size toward the optimal scale.

To construct the Malmquist productivity index of firm $k$ ' between $t$ and $t+1$, the following four distance functions are calculated using the DEA approach: $\mathrm{D}_{0}^{\mathrm{t}}\left(\mathrm{x}^{\mathrm{t}}, \mathrm{y}^{\mathrm{t}}\right)$, $\mathrm{D}_{0}^{\mathrm{t}+1}\left(\mathrm{x}^{\mathrm{t}}, \mathrm{y}^{\mathrm{t}}\right), \mathrm{D}_{0}^{\mathrm{t}}\left(\mathrm{x}^{\mathrm{t}+1}, \mathrm{y}^{\mathrm{t}+1}\right), \mathrm{D}_{0}^{\mathrm{t}}\left(\mathrm{x}^{\mathrm{t}+1}, \mathrm{y}^{\mathrm{t}+1}\right)$, $\mathrm{D}_{0}^{\mathrm{t}+1}\left(\mathrm{x}^{\mathrm{t}+1}, \mathrm{y}^{\mathrm{t}+1}\right)$. These distance functions are the reciprocals of the output-based Farrell's (1957) measure of technical efficiency. The non-parametric programming models used to calculate the output-based Farrell (1957) measure of technical efficiency for each firm $k^{\prime}=1, \ldots, K$, is expressed as:

$$
\left[G_{0}{ }^{t}\left(x_{k}{ }^{t}, y_{k}{ }^{t}\right)\right]^{-1}=\max \lambda^{, k^{\prime}}
$$

Subject to:

$$
\begin{array}{ll}
\lambda^{k^{\prime}} y_{k, m}^{t} \leq \sum_{k=1}^{k} z_{k}^{t} y_{k, m}^{t} & m=1, \ldots \ldots . M, \\
\sum_{k=1}^{k} z_{k}^{t} x_{k, n}^{t} & n=1, \ldots \ldots . N, \\
\sum_{k=1}^{k} z_{k}^{t} \geq 0 & K=1, \ldots \ldots . K
\end{array}
$$

The computation of $\mathrm{D}_{0}^{\mathrm{t}+1}\left(\mathrm{x}^{\mathrm{t}+1}, \mathrm{y}^{\mathrm{t}+1}\right)$ is similar to Equation 7, where $t+1$ is substituted for $t$.

Construction of the Malmquist index also requires calculation of two mixed-distance functions, which is computed by comparing observations in one time period with the best practice frontier of another time pe- riod. The inverse of the mixed-distance function for observation $k$ ' can be obtained from

$$
\left[\mathrm{D}_{0}{ }^{\mathrm{t}}\left(\mathrm{x}_{\mathrm{k}}{ }^{\mathrm{t}+1}, \mathrm{y}_{\mathrm{k}}{ }^{\mathrm{t}+1}\right)^{-1}\right]=\max \lambda^{\mathrm{k}^{\prime}}
$$

Subject to:

$$
\begin{array}{ll}
\lambda^{k^{\prime}} y_{k, m}^{t} \leq \sum_{k=1}^{k} z_{k}^{t} y_{k, m}^{t} & m=1, \ldots \ldots . . M, \\
\sum_{k=1}^{k} z_{k}^{t} x_{k, n}^{t} \leq x_{k, n}^{t} & n=1, \ldots \ldots \ldots . . N, \\
\sum_{k=1}^{k} z_{k}^{t}=1 & (V R S) \\
z_{k}^{t} \geq 0 & K=1, \ldots \ldots \ldots . . K,
\end{array}
$$

To measure changes in scale efficiency, the inverse output distance functions under the VRS technology are also calculated by adding Equation 5 into the constraints in Equation 7 and 9. Technical change is calculated relative to the CRS technology. Scale efficiency change in each time period is constructed as the ratio of the distance function satisfying CRS to the distance function under VRS, while the pure efficiency change is defined as the ratio of the own-period distance functions in each period under VRS. With these two distance functions with respect to the VRS technology, the decomposition of Equation 1 becomes:

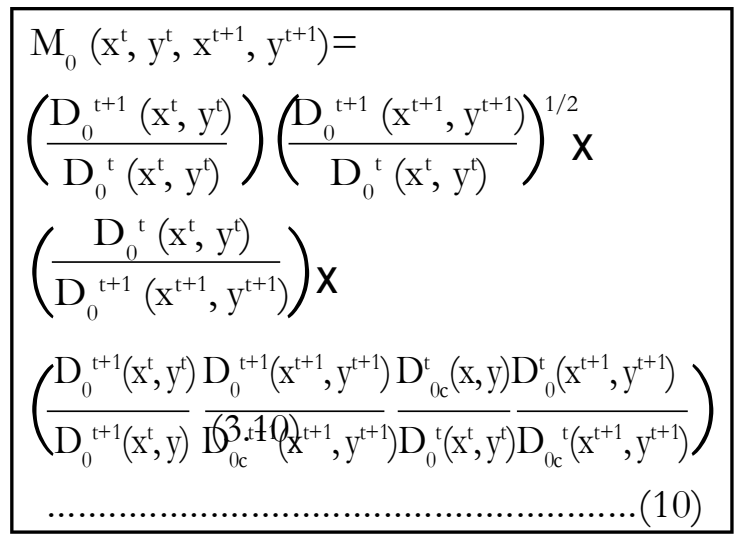


Where

$$
\begin{aligned}
& \left(\frac{D_{0}^{t+1}\left(x^{t}, y^{t}\right)}{D_{0}^{t}\left(x^{t}, y^{t}\right)}\right)\left(\frac{D_{0}\left(x^{t+1}, y^{t+1}\right)}{D_{0}^{t}\left(x^{t}, y^{t}\right)}\right)^{\frac{1}{2}}=\text { Technical Change } \\
& \left(\frac{D_{0}^{t}\left(x^{t}, y^{t}\right)}{D_{0}^{t+1}\left(x^{t+1}, y^{t+1}\right)}\right)=\text { Pure Efficiency Change } \\
& \left(\frac{D_{o c}^{t+1}\left(x^{t}, y^{t}\right)}{D_{0}^{t+1}\left(x^{t}, y^{t}\right)} \frac{D_{0}^{t+1}\left(x^{t+1}, y^{t+1}\right)}{D_{o c}^{t+1}\left(x^{t+1}, y^{t+1}\right)}=\right.\text { Scale } \\
& \left.\frac{D_{o c}^{t}\left(x^{t}, y^{t}\right)}{D_{0}^{t}\left(x^{t}, y^{t}\right)} \frac{D_{0}^{t}\left(x^{t+1}, y^{t+1}\right)}{D_{o c}^{t}\left(x^{t+1}, y^{t+1}\right)}\right) \quad \text { Efficiency } \\
& \text { Change }
\end{aligned}
$$

Note that when the technology in fact exhibits CRS, the scale change factor equals to one and it is the same decomposition as Equation 1.

\section{Generalized Least Squares (GLS)}

In this study we used Generalized Least Squares (GLS) method (with fixed and random effects) to examine the influence of independent variables on the efficiency measure. This methodology has been proposed by Drom and Walker (1996). They used the pooled regression (panel data) model to analyse the influence of funds characteristic (i.e., asset size, expense ratios, portfolio turnover, load/no load status, and primary goal for a fund) on annualized unadjusted and risk adjusted returns. Panel regression models are based on panel data. Panel data consists of observations on the same cross-sectional, or individual, units over several time periods (Gujarati 2003). Pooling or combining, we can write the function as:

$$
\mathrm{Y}_{\mathrm{it}}=\alpha+\beta_{1} \ln \mathrm{X}_{1 \mathrm{it}}+\beta_{2} \ln \mathrm{X}_{2 \mathrm{it}}+\mathrm{u}_{\mathrm{it}} \ldots
$$

where $Y$ represents efficiency, $\alpha$ is the intercept, $u$ is the error term and $X_{1}$ and $X_{2}$ are the respective fund size and profitability, while $i$ stands for the $i$ th cross sectional unit and $t$ for the th time period.

Panel data are better suited to study the dynamics of change and panel data enable us to study more complicated behavioural models. Despite their substantial advantages, panel data suffers from several estimation and inference problem. Since such data involve both cross-section and time dimensions, problems that plague cross-sectional data (e.g., heteroscedasticity) and time series data (e.g., autocorrelation) need to be addressed. There are several estimation techniques to address one or more of these problems (Gujarati 2003). The two most prominent including: (i) the Fixed Effects Model (FEM); and (ii) the Random Effects Model (REM) or Error Components Model (ECM).

In the FEM, the intercept in the regression model is allowed to differ among individuals in recognition of the fact that each individual, or cross sectional, unit may have some special characteristics of its own. To see this, model (11) is rewritten as follows:

$$
\mathrm{Y}_{\mathrm{it}}=\alpha_{\mathrm{i}}+\beta_{1} \ln \mathrm{X}_{1 \mathrm{it}}+\beta_{2} \ln \mathrm{X}_{2 \mathrm{it}}+\mathrm{u}_{\mathrm{it}}
$$

where we put the subscript $i$ on the intercept term to suggest that the intercepts of the twenty-six funds may be different. Differences may be due to special features of each company, such as managerial style or management philosophy.

To take into account the differing intercepts, one can use dummy variables. The FEM using dummy variables is known as the least-squares dummy variable (LSDV) model. The FEM is appropriate in situations where the individual specific intercept may be correlated with one or more regressors. A disadvantage of LSDV is that it consumes a lot of 
degrees of freedom when the number of cross-sectional units, $n$, is very large, in which case we will have to introduce $n$ dummies (but suppress the common intercept term).

An alternative to FEM is REM. In the ECM, it is assumed that the intercept of an individual unit is a random drawing from a much larger population with a constant mean value. The individual intercept is then expressed as a deviation from this constant mean value. One advantage of the ECM over FEM is that it is economical in the degrees of freedom, as we do not have to estimate $n$ cross-sectional intercepts. We need only to estimate the mean value of the intercept and its variance. The ECM is appropriate in situations where the (random) intercept of each cross sectional unit is uncorrelated with the regressors.

The formula of the ECM is as Equation 13.

$$
\begin{aligned}
Y_{i t} & =\alpha+\beta_{1} \ln X_{1 i t}+\beta_{2} \ln X_{2 i t}+\varepsilon_{i t}+u_{i t} \\
& =\alpha+\beta_{1} \ln X_{1 i t}+\beta_{2} \ln X_{2 i t}+w_{i t} \ldots \ldots
\end{aligned}
$$

where $\mathrm{w}_{\mathrm{it}}=\varepsilon_{\mathrm{it}}+\mathrm{u}_{\mathrm{it}}$

The composite error term $w_{i t}$ consists of two components, $\varepsilon_{i t}$, which is the cross section, or individual-specific, error component, and $u_{i p}$ which is the combined time series and cross-section error component.

The Hausman test is used to identify which model is better to adopt whether it is the FEM or ECM. The Hausman test tests the null hypothesis that the coefficients estimated by the efficient random effects estimator are the same as the ones estimated by the consistent fixed effects estimator. If we have insignificant P-value, Probability Chisquared larger than confidence levels then, it is safe to use the random effects. If we get a significant P-value, however, we should use fixed effects.

\section{Data}

As in 2005, there were 329 licensed mutual funds established in Indonesia. They consist of 33 money market funds, 170 fixed income funds, 78 balanced funds and 30 equity funds (Bapepam-Lk 2006). However, in this study, we choose 14 fixed income, 9 balanced funds and 3 equity funds as the sample. Thus, the total of sample in this study is only 26 Indonesian mutual funds including 3 Islamic funds. The main reason for considering only 26 funds in this study is due to the availability of complete information on these funds. Since the DEA is suitable to be used for a small sample size, it is not vulnerable to the disproportion of small sample error as in the econometric model (Dogan and Fausten 2003). This provides more motivation for the study to adopt this model in assessing the performance of 26 mutual funds in Indonesia, i.e., AAA Bond Fund, Batasa Syariah, Bhakti Big Nusantara, Bhakti Big Palapa, Big Dana Likuid, BNI Berkembang, BNI Dana Berbunga Dua, BNI Dana Plus, Dana Tetap Optima, Danareksa Anggrek, Danareksa Mawar, Danareksa Syariah Berimbang, Mahanusa Dana Kapital, Mahanusa Obligasi Pemerintah, Mahanusa PDPTAN Tetap Negara, Mandiri Dana Pendapatan Tetap, Manulife Dana Campuran, Manulife Pendapatan Bulanan, Manulife Phinisi Dana Saham, Mega Dana Kombinasi, Mega Dana Obligasi Medali, Nikko Bond Nusantara, Nikko Bunga Nusantara, Nikko Gebyar Indonesia, PNM Syariah, and Si Dana Fleksi.

The data for this study are collected from the annual report and prospectus of the selected mutual funds which are the data for 
inputs and output are mainly gathered from the Bloomberg Database between 2004 and 2007 period, while the funds characteristics, i.e., fund size and profitability are taken from Bapepam's website between 2005 and 2006 period.

There is no consensus among researchers and investors as to which input and output variables should be included in a DEA model unambiguously. We define our variable selection based on historical evidence, subjective judgment and data availability. Based on theories and empirical studies, we can identify many variables that are used as inputs such as expense ratio, front-end loads, redemption fee and turnover, and most researchers used total return as output (Ippolito 1989).

Table 4. Input-Output Specifications

\begin{tabular}{|c|c|c|c|c|}
\hline & Variable & Indonesian Mutual Funds & Source & Previous Studies \\
\hline \multirow[t]{3}{*}{ Input } & $\begin{array}{l}\text { Front-end } \\
\text { Load/entry } \\
\text { fee }\end{array}$ & $\begin{array}{l}\text { This is a fee charged for the } \\
\text { purchased of funds shares } \\
\text { unit and made at the time } \\
\text { of initial purchase. } \\
\text { This is usually in } \\
\text { percentage that is charged } \\
\text { on NAV per unit }\end{array}$ & Bloomberg & $\begin{array}{l}\text { An entry fee paid by inves- } \\
\text { tors at the time of purchas } \\
\text { ing funds. (Galagedera and } \\
\text { Silvapulle 2002) }\end{array}$ \\
\hline & $\begin{array}{l}\text { Redemption/ } \\
\text { exit fee }\end{array}$ & $\begin{array}{l}\text { This is a fee that may be } \\
\text { charged to the investors } \\
\text { when the fund is sold. } \\
\text { This is percentage that } \\
\text { is charged on NAV per unit }\end{array}$ & Bloomberg & $\begin{array}{l}\text { A fee paid when selling the } \\
\text { mutual fund (Galagedera } \\
\text { and Silvapulle 2002) }\end{array}$ \\
\hline & $\begin{array}{l}\text { Expense } \\
\text { Ratio }\end{array}$ & $\begin{array}{l}\text { Amount investors pay for } \\
\text { expenses incurred in } \\
\text { operating a mutual fund. } \\
\text { This money is deducted } \\
\text { from the fund's current } \\
\text { income and disclosed in the } \\
\text { annual report. }\end{array}$ & Bloomberg & $\begin{array}{l}\text { The costs incurred by the } \\
\text { mutual fund in operating } \\
\text { the portfolio, including } \\
\text { administrative expense and } \\
\text { advisory fee paid to the } \\
\text { investment manager. } \\
\text { (Murthi et al., 1997) }\end{array}$ \\
\hline Output & $\begin{array}{l}\text { Total } \\
\text { Return }\end{array}$ & $\begin{array}{l}\text { It is the annual return, } \\
\text { expressed in percentage } \\
\text { terms. Bloomberg calculation } \\
\text { of total return is determined } \\
\text { each year by taking the change } \\
\text { in annually Net Asset Value } \\
\text { (NAV), reinvesting all income } \\
\text { and capital-gains distributions } \\
\text { during that year, and dividing } \\
\text { by the starting NAV. }\end{array}$ & Bloomberg & $\begin{array}{l}\text { Returns are measured as } \\
\text { the percentage annualized } \\
\text { total rate of return for the } \\
\text { fund (treating all dividends } \\
\text { as reinvested), net of fees } \\
\text { and expenses and before } \\
\text { any load charges. (Dorm } \\
\text { and Walker 1996). }\end{array}$ \\
\hline
\end{tabular}


Thus, the initial model of this study will employ some variables such as charge fees namely front-end loads and redemption fees, and management expense ratio as the input, while total return as the output. However, the turnover ratio is excluded due to its unavailability. Table 4 summarises the inputoutput used to examine the efficiency of mutual funds using DEA.

In the GLS estimation, this study employs fund size and profitability as the independent variables and Total Factor Productivity (TFP) as the dependent variable. With the exception of the dependent variable, all independent variables are taken in the natural logarithm functions.

\section{Empirical Results, Discussion, and Implications}

\section{Descriptive Statistics}

Table 5 shows the descriptive statistics of inputs and outputs of the 26 mutual funds industry across categories in Indonesia during the period of study. Si Dana Fleksi was found to have the highest amount of frontend loads within the period of study, while
Manulife Phnisi Dana Saham (equity), Manulife Dana Campuran (balanced funds) and Manulife Pendapatan Bulanan (debt) were recorded to have the lowest front-end loads to the investors. As for redemption fees, Mahanusa Phnisi Dana Saham seems to have the highest, while BNI Dana Berbunga Dua, BNI Dana Plus, BNI Berkembang and PNM Syariah have the lowest redemption fees, respectively.

In terms of expense ratio, AAA Bond Fund seems to have the lowest expense ratio to the investors, while Manulife Phnisi Dana Saham recorded the highest expense ratio. As for the output, Mahanusa Dana Kapital (balanced funds) has the highest output; return within the period of analysis, while Mandiri Pendapatan Tetap (debt) has the lowest return compared to the others. ${ }^{5}$ On average, the amount of front-end loads, redemptions fee and expense ratio were Rp16.17, Rp27.67 and Rp45.92, respectively. Meanwhile, the average return was 113.21 percent.

\section{The DEA's Findings}

In this section we will report the findings of production frontier and efficiency level of mutual funds, the productivity per-

Table 5. Descriptive Statistics of Inputs and Outputs, 2004-2007

\begin{tabular}{lccccc}
\hline Input & Mean & Median & Maximum & Minimum & S.D \\
Front-end loads (Rp/unit) & 16.174 & 13.395 & 73.980 & 0.000 & 14.740 \\
Redemptions fee (Rp/unit) & 27.672 & 13.665 & 473.060 & 0.000 & 70.204 \\
Expense ratio (Rp/unit) & 45.915 & 30.850 & 279.110 & 7.940 & 43.029 \\
Output & & & & & \\
\hline Total return (\%) & 113.207 & 111.715 & 164.090 & 75.760 & 15.956
\end{tabular}

${ }^{5}$ The details of individual mutual funds inputs and output are available with the author upon request. 
formance of individual mutual funds, and the productivity performance for the entire industry.

\section{Production Frontier and Efficiency}

As the Malmquist productivity index is directly related to measures of efficiency, the study reports first the efficiency changes for 26 mutual funds industry from 2004-2007. Table 4.2 shows the efficiency of the mutual funds industry across various categories under constant returns to scale (CRS) and variable returns to scale (VRS). The value of unity implies that the firm is on the industry frontier in the associated year. The value less than unity implies that the firm is below the frontier or technically inefficient. Hence, the lower the values from unity, the more inefficient it is compared to the values closer to one.

Table 6 reports that the AAA Bond Fund, BNI Dana Berbunga, BNI Dana Plus and BNI Berkembang were consistently efficient, both under the CRS and VRS during the period of study. However, Manulife Phnisi Dana Saham, Manulife Dana Campuran, Manulife Pendapatan Bulanan and Nikko Gebyar Indonesia were only found to be consistently efficient under VRS. Manulife Phnisi Dana Saham was the least efficient fund for CRS, while Mega Dana Kombinasi was the least efficient under VRS. The estimates also showed that the AAA Bond Fund, BNI Dana Berbunga Dua, BNI Dana Plus, BNI
Berkembang, Manulife Pendapatan Bulanan and Nikko Gebyar Indonesia have successfully kept pace with technically viable production possibilities and increased their distance to the industrial production frontier for both CRS and VRS.

For Islamic mutual funds, PNM Syariah was the most efficient compared to other Islamic mutual funds under both CRS and VRS. Batasa Syariah was the least efficient under VRS, while Danareksa Syariah Berimbang was only slightly efficient for CRS. However, all selected Islamic mutual funds were more efficient compared to their conventional counterparts such as Bhakti Big Nusantara, Big Dana Liquid, Dana Tetap Optima, Mandiri Dana Pendapatan Tetap, Mega Dana Kombinasi, Mega Dana Obligasi and Si Dana Fleksi under VRS, while for CRS, only PNM Syariah was found to be more efficient as compared to the average efficiency of the mutual funds industry in Indonesia.

The values in Table 6 display the percentage of the realized output level compared to the maximum potential output level at the given input mix. For instance, Batasa Syariah in 2004 produced 72.1 percent of its potential output and Nikko Bond Nusantara produced 86.2 percent of its potential output under the CRS version. On the other hand, under the VRS version, Batasa Syariah as well as Nikko Bond Nusantara respectively produced 88.6 and 99.7 percent of its potential output in the same year. 


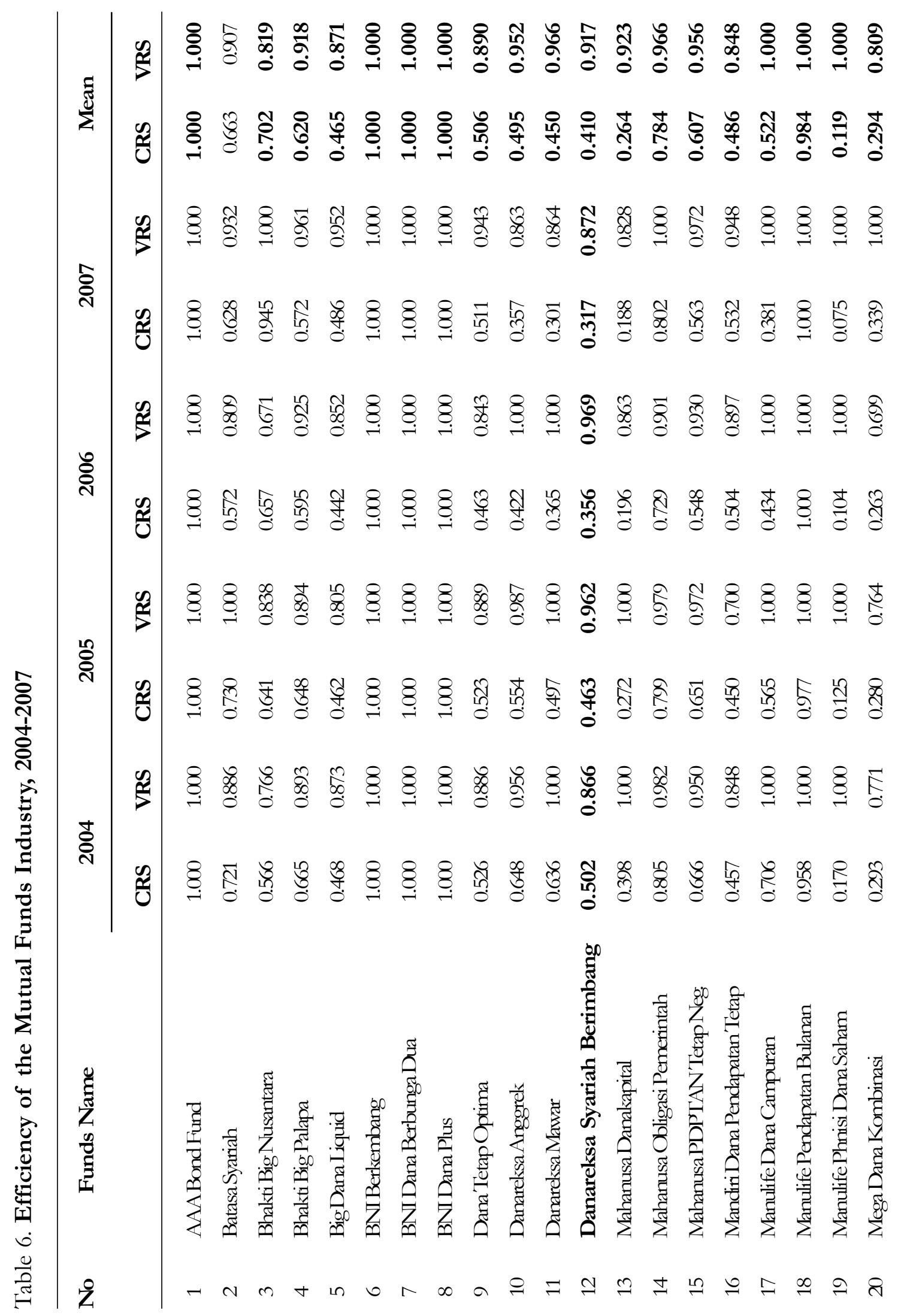


Gadjah MadaInternational Journal of Business-May-August $\operatorname{Vol}$ 14,No. 2, 2012

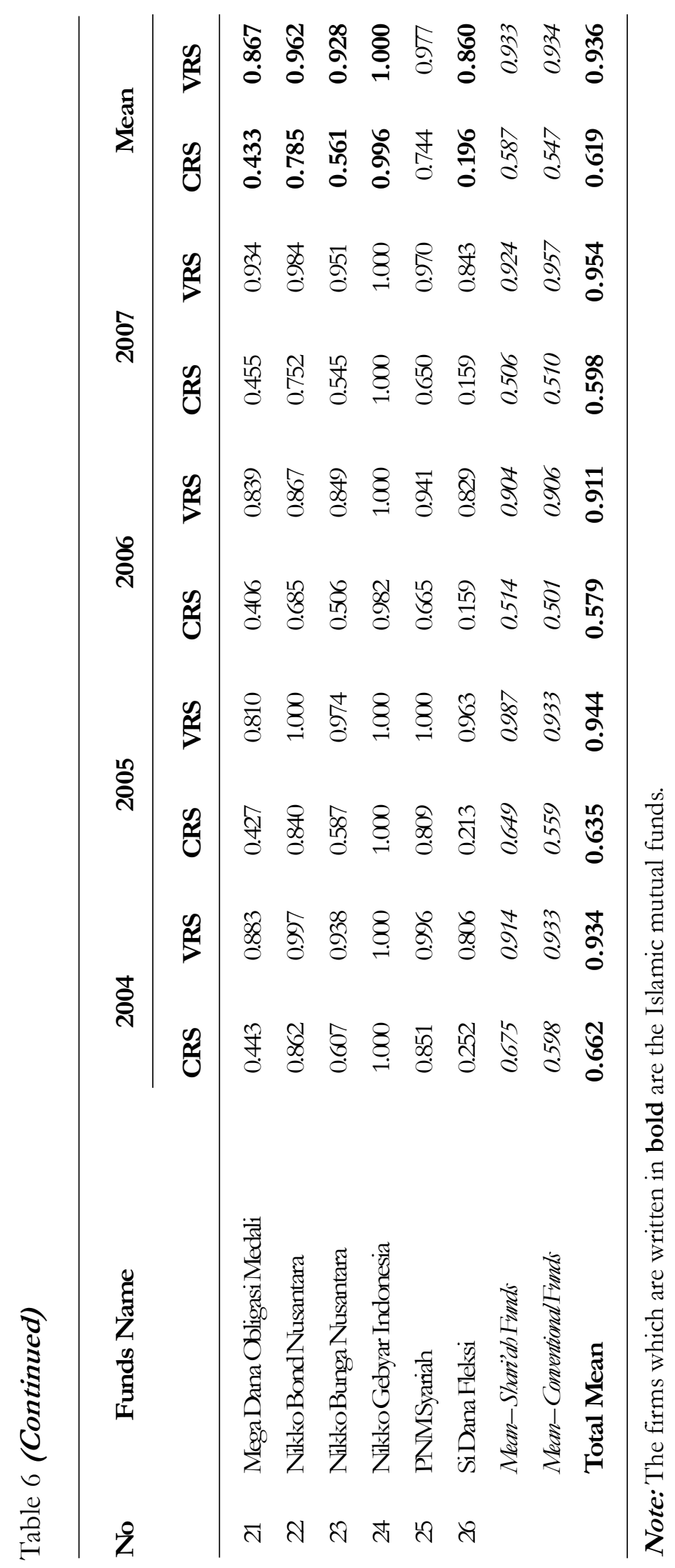


Table 7. Summary of Means' Malmquist Productivity Index, 2004-2007

\begin{tabular}{|c|c|c|c|c|c|c|}
\hline No & Funds Name & TFPch & EFFch & ГECHch & PEch & SEch \\
\hline 1 & AAA Bond Fund & 0.940 & 1.000 & 0.940 & 1.000 & 1.000 \\
\hline 2 & Batasa Syariah & 0.889 & 0.995 & 0.931 & 1.017 & 0.939 \\
\hline 3 & Bhakti Big Nusantara & 1.052 & 1.186 & 0.887 & 1.093 & 1.085 \\
\hline 4 & Bhakti Big Palapa & 0.871 & 0.951 & 0.916 & 1.025 & 0.928 \\
\hline 5 & Big Dana Liquid & 0.946 & 1.012 & 0.934 & 1.029 & 0.984 \\
\hline 6 & BNI Berkembang & 0.781 & 1.000 & 0.781 & 1.000 & 1.000 \\
\hline 7 & BNI Dana Berbunga Dua & 0.935 & 1.000 & 0.935 & 1.000 & 1.000 \\
\hline 8 & BNI Dana Plus & 0.944 & 1.000 & 0.944 & 1.000 & 1.000 \\
\hline 9 & Dana Tetap Optima & 0.923 & 0.990 & 0.932 & 1.021 & 0.970 \\
\hline 10 & Danareksa Anggrek & 0.767 & 0.820 & 0.935 & 0.966 & 0.848 \\
\hline 11 & Danareksa Mawar & 0.729 & 0.780 & 0.935 & 0.952 & 0.818 \\
\hline 12 & Danareksa Syariah Berimbang & 0.807 & 0.858 & 0.940 & 1.002 & 0.856 \\
\hline 13 & Mahanusa Danakapital & 0.730 & 0.779 & 0.937 & 0.939 & 0.830 \\
\hline 14 & Mahanusa Obligasi Pemerintah & 0.938 & 0.999 & 0.940 & 1.006 & 0.993 \\
\hline 15 & Mahanusa PDPTAN Tetap Negara & 0.885 & 0.946 & 0.936 & 1.008 & 0.938 \\
\hline 16 & Mandiri Dana Pendapatan Tetap & 0.986 & 1.052 & 0.938 & 1.038 & 1.013 \\
\hline 17 & Manulife Dana Campuran & 0.770 & 0.814 & 0.945 & 1.000 & 0.814 \\
\hline 18 & Manulife Pendapatan Bulanan & 0.959 & 1.015 & 0.945 & 1.000 & 1.015 \\
\hline 19 & Manulife Phnisi Dana Saham & 0.696 & 0.762 & 0.913 & 1.000 & 0.762 \\
\hline 20 & Mega Dana Kombinasi & 0.987 & 1.050 & 0.940 & 1.090 & 0.963 \\
\hline 21 & Mega Dana Obligasi Medali & 0.943 & 1.009 & 0.935 & 1.019 & 0.990 \\
\hline 22 & Nikko Bond Nusantara & 0.888 & 0.955 & 0.924 & 1.005 & 0.960 \\
\hline 23 & Nikko Bunga Nusantara & 0.892 & 0.965 & 0.924 & 1.005 & 0.960 \\
\hline 24 & Nikko Gebyar Indonesia & 0.913 & 1.000 & 0.913 & 1.000 & 1.000 \\
\hline 25 & PNM Syariah & 0.831 & 0.914 & 0.909 & 0.991 & 0.922 \\
\hline \multirow[t]{4}{*}{26} & Si Dana Fleksi & 0.807 & 0.858 & 0.941 & 1.015 & 0.845 \\
\hline & Mean - Shari'ah Funds & 0.842 & 0.921 & 0.927 & 1.003 & 0.905 \\
\hline & Mean - Conventional Funds & 0.877 & 0.948 & 0.924 & 1.009 & 0.941 \\
\hline & Mean & 0.872 & 0.944 & 0.925 & 1.008 & 0.936 \\
\hline
\end{tabular}

Note: See Table 6

TFPch $=$ Total Factor Productivity Change; EFFch = Efficiency Change; TECHch = Technical Change; PEch $=$ Pure Efficiency Change; SEch $=$ Scale Efficiency Change 
As presented by the weighted geometric in Table 6, the average efficiency for the entire industry decreased from 2004 to 2006 before it slightly increased in 2007 under the CRS version. Meanwhile, under VRS, the geometric mean showed a slight increase from 93.4 percent in 2004 to 94.4 percent in 2005 . However, it declined in 2006 before increased again to 95.4 percent in 2007 . Increasing efficiency in 2005 may be driven by increasing mutual funds' Net Asset Value (NAV) up to February 2005 and reached a high of Rp113.6 trillion. However, in March 2005, the industry was thrown into turmoil since the Central Bank Rate (or in Indonesian acronym known as SBI - Sertifikat Bank Indonesia), which is widely used as the benchmark in the market, rose to a higher-than-expected inflation, which weakened of the rupiah, and rising fuel prices.

Higher interest rates depressed the price of bonds, which translated into a lowered NAV. In other words, many investors would be worried so that may cause massive redemptions from rupiah fixed income funds that causes a significant reduction in total NAV. Redemptions finally peaked in September 2005 when the net asset value dropped from Rp113.6 trillion in February to Rp32.9 trillion and in December, it reached a low of Rp29.4 trillion. Moreover, in January 2006 it slightly declined to Rp28.5 trillion before it increased at the end of 2006 to Rp. 51.62 trillion. This is due partly to the government policy to decrease the interest rate of SBI in order to motivate the investors to move their funds to mutual funds. Besides that, the substantial growth in the mutual fund industry was mainly caused by the good climate on the Indonesian macro-economy conditions during 2006 and it continued in 2007.

\section{Productivity for the Entire Industry}

Table 7 shows the performance of the Malmquist TFPI of Indonesia's mutual fund industry between 2004 and 2007. On the average, Bakti Big Nusantara recorded the highest growth in TFPI with 5.2 percent. Next, the efficiency and technical changes for this fund were 18.6 and -11.3 percent, respectively. However, Manulife Phnisi Dana Saham had the lowest TFPI with -30.4 percent, which was mostly contributed to by efficiency regress (-23.8 percent). On the average, deterioration of the TFPI of mutual funds industry in Indonesia was mostly due to technical change ( -7.5 percent) whereas efficiency also contributed to a negative change (-5.6 percent). Meanwhile, the efficiency change was mostly contributed to by pure efficiency ( 0.8 percent) rather than scale efficiency which experienced a deterioration of -6.4 percent. This shows that the larger the size of the funds, the lower their efficiency changes.

In addition, Batasa Syariah had an average TFP growth higher than the average TFP growth of conventional counterparts, while the average TFP growth of Danareksa Syariah Berimbang and PNM Syariah were lower than the average TFP growth of conventional ones. Likewise, both mean efficiency changes and pure efficiency of Batasa Syariah were also higher than the average efficiency change of conventional ones. However, Danareksa Syariah Berimbang had an average technical efficiency change growth higher than the average of conventional mutual funds, while the average of technical efficiency changes of Batasa Syariah and PNM Syariah were lower than the average of conventional mutual funds. All in all, Islamic mutual funds were found to be relatively less productive 
as compared to their conventional counterparts.

\section{The GLS Findings}

In order to examine the influence of the funds' characteristics on the TFPI and its components, the GLS regression analysis was conducted on the panel data based on the Fixed Effects Model (FEM) and Random Effects Model (REM). As discussed in the previous chapter, the estimation technique with fixed effects assumes that there are two residuals or error terms. First are time effects, which are assumed to be constant for each fund in each period. The second are indi-

Table 8.GLS Estimation Results with FEM and REM (Dependent Variable: TFPI)

\begin{tabular}{lcc} 
Variables & FEM & REM \\
\hline Constant & $\begin{array}{c}1.5432^{*} \\
(11.9772)\end{array}$ & $\begin{array}{l}\text { (8.1481* } \\
\text { Fund Size }\end{array}$ \\
& $-0.0570^{*}$ & $-0.0211^{* * *}$ \\
& $(-4.8633)$ & $(-1.6970)$ \\
Profitability & -0.0224 & -0.0050 \\
& $(-1.0129)$ & $(-0.6431)$ \\
R $^{2}$ & 0.7559 & 0.5891 \\
Adjusted R & 0.4814 & 0.5634 \\
F-statistic & 2.7534 & 22.9420 \\
Prob(F-statistic) & 0.0072 & 0.0000 \\
Hausman Test & & \\
Chi-Sq. Statistic & 15.712 & \\
Probability & 0.000 & \\
\hline
\end{tabular}

Note: Figures in parentheses denote t-statistic values of the regressions coefficients;

$*$, ** and $* * *$ indicate that the coefficient is statistically significant at level 1 percent, 5 percent, 10 percent, respectively vidual effects which are assumed to be constant for each fund company in each period. The fixed effects take into account the individuality for each fund industry (cross sectional) and produce the various intercepts but still assume that the slope coefficients are constant across the funds industry. In other words, the intercept value in the regression model is allowed to differ within the funds industry. Meanwhile, the estimation technique with random effect assumes that the intercept of an individual unit is a random drawing from a much larger population with a constant average value. Error component, $\varepsilon_{i t .}$ represents the gap of intercept of an individual unit from the average value.

In empirically exploring the effects of funds characteristics on the performance of mutual funds industry in Indonesia, the study examines the effects of funds characteristics on mutual funds' Total Factor Productivity Index (TFPI).

Table 8 exhibits the result of GLS when the TFP is regressed against the firm's specific characteristic based on both FEM and REM. Under the FEM, the adjusted- $\mathrm{R}^{2}$ value shows that 48.1 percent of the variation in the TFP is explained by a set of independent variables. It is found that the fund size negatively and significantly affects TFP, while profitability is found to be insignificant in affecting the TFP. In terms of REM, the adjusted $\mathrm{R}^{2}$ values shows 56.3 percent. It was found that the coefficient sign for the fund size is negative and significant, while profitability is insignificant in affecting TFP.

Meanwhile, the Hausman statistics are used to know the best estimation model between the fixed and random effects. The random effects model assumes that the random effects are uncorrelated with the explanatory variables; otherwise there would be an 
endogeneity problem, which in turn would make the estimators inconsistent. The Hausman Test for Correlated Random Effects tests this hypothesis. As described in the previous chapter, if we get an insignificant P-value or Probability Chi-Sq. larger than confidence levels, then it is safe to use random effects. If we get a significant P-value, however, we should use fixed effects. Based on the test output given in table above, the test suggests to reject the null hypothesis since the Probability Chi-Sq. is less than 0.01. This provides evidence that the assumption that the random effects should be uncorrelated to the explanatory variables is not true for this dataset. Therefore, the estimation results with fixed effects are better than random effects.

\section{Conclusion}

The first study objective is to assess the relative efficiency of the mutual fund companies in Indonesia. On average, the Total Factor Productivity (TFP) had decreased 12.8 percent within the period of 2004-2007 with 2006-2007 recording the lowest growth (-19.7 percent). However, the highest technical efficiency was recorded in the period of 20052006 at the rate of 11.4 percent, while 1.4 percent was recorded in the period of 20062007. It is necessary to note that the existence of a negative growth in TFP of the mutual funds industry in Indonesia has been mainly caused by a negative change in efficiency (-5.6 percent), while technical efficiency also contributed to a greater negative change ( -7.5 percent $)$ to the overall decrease in the TFP growth.

The results indicate that the mutual funds industry experienced diminished productivity and became more technically inefficient from 2004 to 2007. The study concluded that much of the inefficiency increased overtime which was due to the failure of the mutual funds to adopt technological advances made by a few efficient mutual funds. Although the efficiency change experienced a negative growth, the subcomponent of this change, namely pure efficiency, showed a slight improvement ( 0.8 percent). Thus, the finding indicates that the smaller the size of the companies, the larger the probability for the companies to be more efficient in using their inputs to generate more outputs.

Compared to the conventional mutual funds, the average TFP, efficiency and scale efficiency growth of the three Islamic mutual funds, Batasa Syariah, Danareksa Syariah Berimbang and PNM Syariah, were found to be lower than the conventional funds, with the exception of Batasa Syariah. However, in technical efficiency, the average growth of Batasa Syariah and Danareksa Syariah Berimbang was found to be higher than their conventional counterparts. Meanwhile, PNM Syariah recorded the lowest growth in technical efficiency (-9.1 percent). Finally, in the case of pure efficiency, Danareksa Syariah Berimbang and PNM Syariah were below average, while Batasa Syariah was above average in mutual fund industry in Indonesia. Therefore, improving mutual funds TFP, technical efficiency, efficiency and scale efficiency changes are the best ways for Islamic mutual funds in order to be in a better position and to gain a competitive edge over the conventional mutual funds. Additionally, the efficiency change was mainly contributed to by the pure efficiency ( 0.8 percent) rather than the scale efficiency (-6.4 percent). This indicates that the smaller the size of the fund, the higher their efficiency change.

Meanwhile, in measuring the effect of a mutual fund's characteristics on efficiency, it was found that the funds size negatively and significantly influences TFPI, indicating 
that small funds may have higher performance and become more efficient. Profitability was insignificantly associated to TFPI.

In general, the TFPI experienced a negative growth (-12.8 percent) during the period of study 2004-2007. This indicates that the averages of selected mutual fund companies in Indonesia are efficient in using their inputs to generate more outputs. This is not surprising since some mutual fund companies have experienced a crisis of massive redemption particularly at the end of 2005 which the Indonesian macro-economy condition was relatively unstable and had caused an increase in the interest rate (about $12.75 \%$ ) as a consequence of a rise in world fuel price and higher inflation. Therefore, the instability during the financial crisis is still fresh in the minds of many investors. An important program for the near term should be to develop a base of individual investors. Moreover, the inefficiency of funds was also mainly caused by the failure of mutual funds to adopt technological advances. This study suggests that the mutual funds industry in Indonesia has a great opportunity to promote its TFP through an improvement in the technical element such as optimizing the use of information technology in providing good services to customers (investors).

Generally, the average productivity of the Islamic mutual funds (i.e., Danareksa Syariah Berimbang and PNM Syariah) is relatively below average of their conventional funds. However, in order to sustain in the long-term, the Islamic mutual funds has to be internally efficient and technologically advanced in order to compete with its conventional counterparts. Therefore, training and technical expertise should be constantly upgraded along with technological evolution. This can be done through education and training programs intended to improve managerial ability, or extension programs designed to speed up the adoption of new technologies.

Meanwhile, small funds appeared to be more efficient than larger funds. The study suggests that market competition motivates more disciplinary effects on small funds. Finally, profitability insignificantly affects TFPI, suggesting that profitability has no effect on the funds' performance.

Despite some studies having proved that there are no significant differences between the parametric approach and non parametric approach, we suggest that future study be conducted by measuring the efficiency using both approaches especially the Stochastic Frontier Approach (SFA) and DEA. Moreover, we also suggest that the future study be conducted on Indonesia should use more comprehensive variables such turnover ratio, risk (standard deviation or beta) and also add sample mutual funds, i.e., 50 mutual funds or 100 mutual funds. Finally, we hope that in the future, there will be studies comparing the efficiency of the Indonesian mutual funds industry with the mutual funds industry from other countries and regions. 


\section{References}

Abd. Majid, M. S., and H. Maulana. 2010. Assessing performance of mutual funds in Indonesia. Journal of Economic Cooperation and Development 31 (4): 49-76.

Abdullah, F., T. Hasan, and S. Mohamad. 2007. Investigation of performance of Malaysian Islamic unit trust funds: Comparison with conventional unit trust funds. Managerial Finance 33: 142-153.

Alam, I., and R. Sickles. 1995. Long run properties of technical efficiency in the U.S. airline industry. Mimeo. Rice University.

Annuar, M. N., M. Shamsher, and M. H. Ngu. 1997. Selectivity and timing: Evidence from the performance of Malaysian unit trusts. Pertanika Journal of Social Science and Humanities 5: 45-57.

Asai, S., and J. Nemoto. 199. Measurement of efficiency and productivity in regional telecommunications business. Institute for Post and Telecommunication Policy Discussion Paper 3 (June 25).

Banker, R. D., A. Charnes and W. W. Cooper. 1984. Some models for estimating technical and scale efficiencies in data envelopment analysis. Management Science 30: 1078-1092.

Basso, A., and S. Funari. 2001. Theory and methodology: A data envelopment analysis approach to measure the mutual fund performance. European Journal of Operational Research 135: 477-492.

Berger, A. N., and D. B. Humprey. 1997. Efficiency of financial institution: international survey and direction for future research. European Journal of Operation Research 98: 175-212.

Charnes, A., W. W. Charnes, and E. Rhodes. 1978. Measuring the efficiency of decision making units. European Journal of Operational Research 3: 429-444.

Chen, Z., and R. Lin. 2006. Mutual fund performance evaluation using data envelopment analysis with new risk measures. OR Spectrum 28: 375-398.

Coelli, T. J. 1996. A guide to DEAP version 2.1: A data envelopment analysis (Computer) Program. Working Paper 8 (96). Centre for Efficiency and Productivity Analysis (CEPA). University of New England.

Dogan, E., and D. K. Fausten. 2003. Productivity and technical change in Malaysian banking (1989-1998). Asia-Pacific Financial Markets 10: 205-237.

Fare, R., and C. A. K. Lovell. 1978. Measuring the technical efficiency of production. Journal of Economic Theory 19: 150-162.

Fare, R., G. Shawna, L. Bjorn, and L. Ross. 1989. Productivity development in swedish hospitals: A Malmquist output index approach. Mimeo.

Fare, R., G. Shawna, N. Mary, and Z. Zhongyang. 1994. Productivity growth, technical progress and efficiency change in industrialized countries. American Economic Review 84: 66-83.

Farrell, M. 1957. The measurement of productive efficiency. Journal of the Royal Statistical Society 120: 253281.

Ferdian, I. R., and M. K. Dewi. 2007. Performance analysis of Islamic mutual funds: A comparative study between Indonesia and Malaysia. Paperpresented at the International Conference on Islamic Capital Markets (August 27-29). Jakarta, Indonesia.

Galagedera, D. U. A., and P. Silvapulle. 2002. Australian mutual fund performance appraisal using data envelopment analysis. Journal of Managerial Finance 28: 60-61. 
Ghoul, W., N. Azoury, and P. Karam. 2007. Islamic mutual funds: how do they compare with other religiously-based and ethically-based mutual funds?. Paperpresented at the IIUM International Conference on Islamic Banking and Finance (IICiBF) 23-25 April). IIUM Institute of Islamic Banking and Finance (IIiBF), Kuala Lumpur.

Gujarati, D. N. 2003. Basic Econometrics (4 ${ }^{\text {th }}$ ed.). New York: McGraw-Hill.

Hayat, R. 2006. An empirical assessment of Islamic equity fund returns. Master Thesis. Amsterdam: Free University.

Ippolito, R. A. 1989. Efficiency with costly information: A study of mutual fund performance (19651984). 1989. Quarterly Journal of Economics 104: 1-23.

Jemric, I., and B. Vujcic. 2002. Efficiency of bank in Croatia: A DEA approach. Comparative Economic Studies 44: 169-193.

Jensen, M. C. 1968. The performance of the mutual funds in the period 1945-1964. Journal of Finance 23: 389-416.

Jensen, M. 1972. Optimal utilization of market forecasts and the evaluation of investment portfolio performance. In Szego and Shell (Ed), Mathematical Methods in Investmerit and Finance. North Holland, Amsterdam.

Maghyereh, A.2004. The effect of financial liberalization of the efficiency of financial institutions: The case of Jordanian commercial banks. Savings and Development 28: 235-270.

Murthi, B.P.S., Y. K. Choi, and P. Desai. 1997. Efficiency of mutual funds and portfolio performance measurement: A non-parametric approach. European Journal of Operational Research 98: 408-418.

Md. Taib, F., and M. Isa. 2007. Malaysian unit trust aggregate performance. Managerial Finance 33: 102 121.

Neal, P. 2004. X-efficiency and productivity change in Australian banking. Australian Economic Papers 13: 174-191.

Sharpe, W. F. 1965. Mutual fund performance: Measurement and prediction. The RAND Corporation (March). Santa Monica.

Sharpe, W. F. 1966. Mutual fund performance. Journal of Business 34: 119-138.

Seiford, L. M., and R. M. Thrall. 1990. Recent developments in DEA: the mathematical programming approach to frontier analysis. Journal of Econometrics 46: 7-38.

Sengupta, J. K. 2003. Efficiency test for mutual fund portfolios. Applied Financial Economics 13: 869-876.

Supervisory Capital Market of Indonesia Agency (Bapepam: Badan Pengawas Pasar Modal). Annual Report (Various Issues).

Supervisory Capital Market of Indonesia Agency. 2006-2009. Indonesian Capital Market Master Plan.

Treynor, J. L. 1965. How to rate management of investment funds. Harvard Business Review 43: 63-75.

www.bapepamlk.go.id 